\title{
Individual Approaches to Diagnosis and freatment of Epilepsia (Review)
}

\author{
DOI: $10.17691 / \mathrm{stm} 2018.10 .3 .25$
}

Received December 12, 2017

A.A. Zemlyanaya, MD, PhD, Senior Researcher, Department of Exogenous Organic Disorders and Epilepsy'; A.1. Fedotchev, DSc, Leading Researcher, Laboratory of Reception Mechanisms ${ }^{2}$

IMoscow Research Institute of Psychiatry - a Branch of the V.P. Serbsky National Medical Research Center of Psychiatry and Narcology, Ministry of Health of the Russian Federation, 10 bldg., 3 Poteshnaya St., Moscow, 107076, Russia;

2nstitute of Cell Biophysics of the Russian Academy of Sciences, 3 Institutskaya St., Pushchino, Moscow Region, 142290, Russia

Epilepsy is one of the most common and treatment-resistant neurological diseases; it has heterogenic manifestations and requires individual approaches to its diagnosis and treatment. The ground for such approaches has been laid by modern science-based technologies, currently available in clinical practice. The aim of this review is to analyze publications on personalized approaches to the diagnosis and treatment of epilepsy over the past 10 years. In this review, we discuss the issue of individual markers of epilepsy and their predictive power, new approaches to localizing the epileptic foci, the relationship between the left-sided, right-sided and interhemispheric asymmetry and epileptogenesis, the role of comorbid disorders in epilepsy, as well as the available options for identifying the predictors of treatment efficacy.

Key words: epilepsy; markers of epilepsy; predictors of epilepsy; personalized treatment; antiepileptic drugs.

\section{Introduction}

Epilepsy is one of the most common and treatmentresistant neurological diseases, which can significantly reduce the patient's quality of life [1, 2], and in some cases lead to sudden death [3-5]. According to the WHO estimates, there are more than 50 million people with epilepsy worldwide [6]. About $10 \%$ of world population can expect at least one epileptic attack during their lifetime [7]. Despite the wide use of new antiepileptic drugs, about a third of patients with epilepsy suffer from seizures that are resistant to therapy $[8,9]$. The situation is complicated by the fact that $50 \%$ of patients with epilepsy suffer from affective, cognitive and other psychiatric disorders with no specific treatment options [10]. Therefore, studies on the pathogenesis, diagnosis, and treatment of epilepsy continue to attract a great research interest.

In recent years, the concept of clinical heterogeneity in patients with epilepsy has been recognized [11, 12]; therefore, the development of personalized approaches to the treatment of epilepsy is needed [13, 14]. Thanks to the introduction of modern science-based technologies into clinical practice, the prerequisites for this development are already available. Among them are newly proposed individual markers [15-17] and predictors of the course of the disease $[18,19]$. The dependence of epilepsy on various individual characteristics, such as sex, age, localization of the epileptic focus, the time of the debut etc. has become appreciated. It is important to consider these factors to ensure that the personalized therapeutic approach will result in a successful outcome of the disease.

The review presents a summary of published data on the development of personalized approaches to the diagnosis and treatment of epilepsy over the past 10 years. In this review, we discuss the issue of individual markers of the disease and their predictive power, new approaches to localizing the epileptic foci, the relationship between the left-, right-sided and interhemispheric asymmetry and epileptogenesis, the role of comorbid disorders in epilepsy, as well as the available options for predicting the antiepileptic treatment efficacy.

\section{Localization of epileptic foci}

In recent years, new structural and morphological data have been obtained by using up-to-date diagnostic modalities, such as magnetic resonance imaging (MRI) and voxel-based morphometry; these data indicate different susceptibilities of the cerebral hemispheres to epileptogenesis. Thus, a decrease in the volume of amygdala [20] and abnormalities in the white [21] and gray [22] matters have been observed in patients with left temporal epileptic foci. The authors explain

Corresponding author: Alexander I. Fedotchev, e-mail: fedotchev@mail.ru 
the findings by the destructive impact of the epileptic focus on the left hemisphere, which at an early age is functionally less active and more susceptible to injury induced by epileptic discharges.

The most effective method for determining the source of epileptogenesis is the MRI and its modifications [23]. Thus, according to the functional magnetic resonance mapping - the standard method for revealing lateralization of the speech function in patients with epilepsy [24] — the dominance of the left hemisphere in this function is reduced in focal epilepsy [25]. The motor activity pattern is another good index of epileptic focus localization. For example, authors [26] studied the interhemispheric differences manifested in muscular seizures by monitoring muscular artifacts in the EEG. They found a more pronounced muscular activity in the hemisphere contralateral to the localization of the epileptic focus. In another study [27], the significance of the ictal automatisms in the upper limbs was assessed. It was shown that in patients with lateralized epileptiform EEG discharges, the ipsilateral motor automatisms were more pronounced than the contralateral ones. Some authors believe that by improving the currently used methods of motor analysis it is possible to better characterize the focal seizures by motor automatism [28].

Along with the results of video EEG monitoring, neuroimaging and functional magnetic resonance imaging, the individual symptomatic signs of the disease are of great importance in determining the localization of epileptic foci [29]. For example, in patients with focal epilepsy, the characteristics of prosody (perception of intonation, rhythm, and expressiveness of speech) were found abnormal during the ictal periods. In all these patients, the seizures were localized in the non-dominant hemisphere (most often in the right temporal zone); these findings suggest that the prosody criterion can be used for localizing the source of epileptic seizures in the temporal zone of the non-dominant hemisphere [30].

A certain diagnostic value for the detection of the epileptic focus is attributed to the head and eye aversion at the time of seizures. Thus, in the epileptic status, the direction of the head rotation during a seizure can indicate the lateralization pattern: in the examined patients, the head turned in the direction opposite to the side of the lesion [31]. A quantitative analysis of individual parameters of the head movements during seizures (time of onset, direction, duration, and angular velocity) revealed significant differences between the frontal and temporal locations of the epileptic foci [32]

$A$ rapid and relatively reliable index of the focus lateralization in epilepsy is the test for dichotic listening applied to patients preparing for surgery [33]. In children with rolandic epilepsy and with the left-sided focus localization, the left-hemispheric dominance (a sign of phonologic imbalance) ceased to manifest when the patients were tested for their articulation competence [34]. According to the results of dichotic listening during and after seizures, in children with the left hemispheric speech dominance, epileptic discharges lead to a sharp decrease in the level of word recognition (when listening with the right ear), whereas in healthy kids, the recognition ability increased with word repetition [35].

\section{Left-sided, right-sided, and interhemispheric asymmetry and epileptogenesis}

With its external symmetry, the human body is characterized by many anatomical and functional asymmetries, which have a great clinical significance. In a fundamental review [36], a number of differences between the hemispheres of the human brain are presented; those pertain to structural, functional and behavioral characteristics. The asymmetries in the brain functions, cytoarchitectonics and neurochemistry correlate with gender, age, genetic factors, and hormonal influences; this asymmetry is also reflected in person's behavior, left- or right- sidedness, auditory perception, motor preferences, clarity of sensory analysis, etc. We believe that the knowledge and understanding of these asymmetries are important for making a correct diagnosis and drawing up a well-based treatment plan for patients with epilepsy.

Since the number of patients with a non-right functional asymmetry can reach $30-40 \%$ among those hospitalized in a psychiatric hospital [37], the side dominance factor and its predictive power may play a significant role in patient management. However, there is conflicting information in the literature on the relations between the function asymmetry and epilepsy.

A group of authors [38], after examining 478 patients with epilepsy, found no correlation between the sidedness and patients' clinical characteristics such as sex, age, type of seizures, age of onset of the disease, types of EEG and MRI abnormalities and others. However, most authors note a certain connection between the left- or right- sidedness and epilepsy. In one study [39], the degree of left-sidedness correlated with a more pronounced atypical (right-sided) lateralization of the speech function in temporal epilepsy. Another recent study [40] found a relationship between the leftsidedness and the left-sided localization of the epileptic focus. In our studies [41], there were more left-sided individuals ( $30 \%$ of cases) among patients with temporal epilepsy than in the total population (10\%).

There is also evidence that, with temporal epilepsy, structural and functional abnormalities extend far beyond the epileptogenic temporal zone. Thus, diffusionweighted MRI images of the conducting pathways revealed the presence of impaired frontal-parietal white matter tracts located on the side of the lesion in patients with temporal epilepsy [42]. The authors believe that recurrent epileptic seizures impair primarily the cortical zone integration within the affected hemisphere. In another study [43], patients with temporal epilepsy demonstrated lateralization patterns that concerned four 
brain structures; in three of them (anterior and middle temporal zones and the cerebellum), these deviations were ipsilateral, and in the frontal-parietal zone contralateral to the epileptic focus. An EEG monitoring revealed that the epileptiform activity recorded from the area outside the epileptic focus can disrupt cognitive processes, such as remembering words [44].

\section{Comorbid disorders in epilepsy}

Comorbidity is the presence of two or more syndromes or diseases with different etiology, pathogenesis, and pathophysiology that occur in the same person concomitantly. Studying comorbid disorders in epilepsy is extremely important, as it can contribute to the understanding of pathogenesis of the disease, making the correct diagnosis and prognosis, and choosing an adequate treatment [45-48].

There are different opinions as to what kind of comorbid conditions go along with epilepsy. Some authors [49] believe that patients with epilepsy suffer from migraine, diabetes, chronic fatigue, depression, anxiety, personality, and cognitive disorders 2-5 times more often than those without epilepsy. Other authors [50] suggest that the list of comorbid disorders in epilepsy should include depression, anxiety, psychotic disorders, cognitive and intellectual dysfunctions, disorders caused by antiepileptic drugs, suicidal conditions and consequences of surgical interventions.

Depression is one of the most frequent disorders in patients with epilepsy; it occurs in $20-55 \%$ of cases with recurrent seizures and in 3-9\% of cases in the absence of seizures [51]. Depression in epilepsy can be associated with stress: the patient is chronically stressed due to the "burden of epilepsy" and the acquired helplessness against the threat of recurrent seizures those psychological factors present an obvious risk of depression [52]. There are markers that may indicate a predisposition to depression: those are the baseline asymmetry of the EEG alpha-rhythm (the right parietal activity is lower than the left one) [53] and a relative decrease in the EEG activity in the left frontal zone [54].

Anxiety in epilepsy can occur even more often than depression: from $10-25 \%$ in some reports to more than $50 \%$ in others $[49,55]$. Most authors consider these comorbid disorders as negative affective conditions that accompany epilepsy [56-59] and occur in 33\% of patients [60].

Epilepsy is often accompanied by suicidal disorders, which requires special attention during the initial patient examinations [61]. Magnetic resonance imaging of the brain showed a significant white matter loss in the right frontal zone and a gray matter gain in the left temporal zone in patients with epilepsy and suicidal disorders [62].

By using video EEG monitoring and neuropsychological tests, it has been shown that the degree of cognitive and mental dysfunction increases with an increase in the number of interictal epileptic discharges [63]. The negative impact of seizures on the development of mental functions is mediated by dysregulated signaling pathways and neural networks [64]. The unfavorable prognosis of mental abilities in epilepsy correlates with the early onset of the disease, the presence of focal seizures, the predominance of large and serial epileptic seizures, the occurrence of epileptic status, the deep disturbance of consciousness in the post-ictal period, the frequency and severity of twilight conditions in the inter-ictal period, and the existence of day- and night-time seizures [65].

Cognitive disorders in epilepsy, by most authors, include memory and performance impairments, intellectual disability, reduced processing speed, slow reaction times, attention deficit and other functional abnormalities [66-69]. Cognitive defects are observed in epilepsy both in children [70, 71] and in adults $[72,73]$; these defects are thought to be caused by genetic, molecular and cellular mechanisms common to epilepsy, intellectual disorders and autism spectrum disorders [74].

The course and severity of cognitive impairment in epilepsy are influenced by a number of factors, such as etiology of the disease, age of the patients, type and frequency of seizures, hereditary and psychosocial environmental factors, consequences of surgical intervention, and adverse effects of antiepileptic drugs. An important role in cognitive dysfunctions in epilepsy is played by the factors of location and character of the cerebral lesion [75].

In epilepsy, psychiatric and psychosocial complications are more frequent than in other chronic diseases [76]. They occur in about a third of patients; nevertheless, they have yet to be well studied to develop appropriate methods of treatment [77]. Some authors indicate that antiepileptic drugs can provoke psychopathological symptoms in epilepsy [78, 79]. Other authors emphasize that the risks of psychosis in epilepsy correlate with the early age of epilepsy debut, the presence of epileptic status, hippocampal sclerosis and structural/functional disorders of the left hemisphere [80].

\section{Current options of identifying predictors of the antiepileptic therapeutic efficacy}

In recent studies, the issue of drug resistant epilepsy has become one of the most important. Pharmacoresistance is found in about $30 \%$ of patients with epilepsy and is often accompanied by increased traumatism, psychosocial disorders, and deterioration in the quality of life [81].

It has been established that the main clinical predictors of pharmacoresistance are the presence of psychiatric [82] and depressive [83, 84] disorders, as well as organic brain pathology diagnosed with the MRI $[85,86]$. In adults, the predictors of pharmacoresistance in epilepsy include the early age of the debut, frequent seizures, failure of previous therapy, diffuse epileptiform 
or abnormal baseline EEG activity, and gradual development of brain damage [87].

According to some authors, an adequate choice of pharmacotherapy considering the possible drug interactions and the individual characteristics of the patient may be the way to overcome pharmacoresistance in epilepsy and concomitant diseases [88, 89].

Earlier, we demonstrated that the therapeutic dynamics of seizures can become an important prognostic index of treatment efficacy [90]. In patients with a right-sided profile of interhemispheric asymmetry, the number of complex partial seizures (under antiepileptic therapy) dropped 3 times more than that in patients with a left-sided asymmetry profile [91-93]. It was also established that the profile of interhemispheric asymmetry had a significant impact on the efficacy of anti-seizure therapy in patients with pharmacoresistant epilepsy [94].

In recent years, it has been found that many antiepileptic drugs may have psychotropic effects, which must be taken into account when choosing the treatment strategies. Studies on the latest generation of antiepileptic agents are now under way [95].

\section{Conclusion}

The reviewed publications demonstrate that by the present time, thanks to the innovative technologies, a number of individual markers and predictors of epilepsy have been proposed. Along with that, data on correlations between manifestations of epilepsy and individual patient's characteristics has been accumulated. According to the commonly shared views, these factors should be taken into account when deciding on the patient-oriented treatment of epilepsy; such an approach is expected to ensure positive outcomes of complicated and drug-resistant epilepsy $[88,96]$.

The findings described above may contribute to the development of personalized approaches to the treatment of epilepsy, whose motto is to treat a particular patient and not a disease in general [97]. Due to the poly-etiological nature of epilepsy, most epileptologists agree that such approaches will pave the way to highefficacy antiepileptic therapy [98, 99].

It is worth mentioning that in recent years, an additional approach to personalized diagnosis and treatment of epilepsy has been developed. Specifically, a rapidly developing technology of neurointerfaces has been put forward (see our earlier publication [100]). This technology is based on the feedback signals from the individual bioelectric characteristics of a patient; the method provides highly personalized information that can be used in planning the therapeutic strategy. We have already reported on using the neurointerface technologies to activate cognitive functions [101], for the treatment of attention deficit hyperactivity syndrome [102], and for suppressing stress-induced disorders
[103]. We tend to believe that the brain-computer interface and neurofeedback technologies can also be successfully used in the treatment of epilepsy.

Financial support. This work was supported by grant No.16-06-00133 from the Russian Humanitarian Scientific Foundation and grant No.18-013-01225A from the Russian Foundation for Basic Research.

Conflict of interest. The authors have no conflict of interest.

\section{References}

1. Melikyan E.G., Milchakova L.E., Guekht A.B., Gusev E.I. Quality of life in epileptology. Zhurnal nevrologii i psikhiatrii im. S.S. Korsakova 2008; 108(Suppl 3): 28-35.

2. Melikyan E.G., Gekht A.B. Life quality in epileptic patients. Lechebnoe delo 2011; 1: 1-9.

3. Duncan S., Brodie M.J. Sudden unexpected death in epilepsy. Epilepsy Behav 2011; 21(4): 344-351, https://doi. org/10.1016/j.yebeh.2011.04.056.

4. Shorvon S., Tomson T. Sudden unexpected death in epilepsy. Lancet 2011; 378(9808): 2028-2038, https://doi. org/10.1016/s0140-6736(11)60176-1.

5. Duble S.N., Thomas S.V. Sudden unexpected death in epilepsy. Indian J Med Res 2017; 145(6): 738-745, https://doi. org/10.4103/ijmr.ijmr_548_17.

6. Guerreiro C.A. Epilepsy: is there hope? Indian J Med Res 2016; 144(5): 657-660, https://doi.org/10.4103/ijmr. ijmr_1051_16.

7. Rizvi S., Ladino L.D., Hernandez-Ronquillo L., TéllezZenteno J.F. Epidemiology of early stages of epilepsy: risk of seizure recurrence after a first seizure. Seizure 2017; 49: 4653, https://doi.org/10.1016/j.seizure.2017.02.006.

8. Avakyan G.G., Voronina T.A., Litvinova S.A., Nerobkova L.N., Balabanyan V.U., Nikonova A.A., Avakyan G.N. New approaches in the treatment of epilepsy. Annaly kliniceskoj i eksperimental'noj nevrologii 2017; 11(3): 15-22.

9. Tang F., Hartz A.M.S., Bauer B. Drug-resistant epilepsy: multiple hypotheses, few answers. Front Neurol 2017; 8: 301, https://doi.org/10.3389/fneur.2017.00301.

10. Jensen F.E. Epilepsy as a spectrum disorder: implications from novel clinical and basic neuroscience. Epilepsia 2011; 52(Suppl 1): 1-6, https://doi.org/10.1111/ j.1528-1167.2010.02904.x.

11. Syvertsen M.R., Thuve S., Stordrange B.S., Brodtkorb E. Clinical heterogeneity of juvenile myoclonic epilepsy: follow-up after an interval of more than 20 years. Seizure 2014; 23(5): 344-348, https://doi.org/10.1016/j. seizure.2014.01.012.

12. Zorin R.A., Zhadnov V.A., Lapkin M.M. The heterogeneity of patients with epilepsy in terms of psychological characteristics, quality of life, and a response to anticonvulsant therapy. Nevrologiya, neiropsikhiatriya, psikhosomatika 2017; 9(1S): 5863, https://doi.org/10.14412/2074-2711-2017-1s-58-63.

13. Pisani L.R., Nikanorova M., Landmark C.J., Johannessen S.I., Pisani F. Specific patient features affect antiepileptic drug therapy decisions. Focus on gender, age, and psychiatric comorbidities. Curr Pharm Res 2017; 23(37): 56395648, https://doi.org/10.2174/1381612823666170926103631.

14. Veldiaksova E.D., Yakunina A.V., Pisar A.A. Modern 
capabilities of personalized prescription antiepileptic drugs. Zdorov'e i obrazovanie v XXI veke 2017; 19(4): 56-61.

15. Pitkänen A., Löscher W., Vezzani A., Becker A.J., Simonato M., Lukasiuk K., Gröhn O., Bankstahl J.P., Friedman A., Aronica E., Gorter J.A., Ravizza T., Sisodiya S.M., Kokaia M., Beck H. Advances in the development of biomarkers for epilepsy. Lancet Neurol 2016; 15(8): 843-856, https://doi.org/10.1016/s1474-4422(16)00112-5.

16. Vezzani A., Pascente R., Ravizza T. Biomarkers of epileptogenesis: the focus on glia and cognitive dysfunctions. Neurochem Res 2017; 42(7): 2089-2098, https://doi. org/10.1007/s11064-017-2271-3.

17. van Dijkman S.C., Voskuyl R.A., de Lange E.C. Biomarkers in epilepsy - a modelling perspective. Eur $J$ Pharm Sci 2017; 109S: S47-S52, https://doi.org/10.1016/j. ejps.2017.05.035.

18. Beghi E., Giussani G., Sander J.W. The natural history and prognosis of epilepsy. Epileptic Disord 2015; 17(3): 243-253.

19. Kerr E.N., Fayed N. Cognitive predictors of adaptive functioning in children with symptomatic epilepsy. Epilepsy Res 2017; 136: 67-76, https://doi.org/10.1016/j. eplepsyres.2017.07.015.

20. Silva I., Lin K., Jackowski A.P., Centeno Rda S., Pinto M.L., Carrete H. Jr., Yacubian E.M., Amado D. Absence of gender effect on amygdala volume in temporal lobe epilepsy. Epilepsy Behav 2010; 19(3): 501-503, https://doi. org/10.1016/j.yebeh.2010.08.031.

21. Kemmotsu N., Girard H.M., Bernhardt B.C., Bonilha L., Lin J.J., Tecoma E.S., Iragui V.J., Hagler D.J. Jr., Halgren E., McDonald C.R. MRI analysis in temporal lobe epilepsy: cortical thinning and white matter disruptions are related to side of seizure onset. Epilepsia 2011; 52(12): 2257-2266, https://doi. org/10.1111/j.1528-1167.2011.03278.x.

22. Santana M.T., Jackowski A.P., da Silva H.H., Caboclo L.O., Centeno R.S., Bressan R.A., Carrete H. Jr., Yacubian E.M. Auras and clinical features in temporal lobe epilepsy: a new approach on the basis of voxel-based morphometry. Epilepsy Res 2010; 89(2-3): 327-338, https:// doi.org/10.1016/j.eplepsyres.2010.02.006.

23. Middlebrooks E.H., Ver Hoef L., Szaflarski J.P. Neuroimaging in epilepsy. Curr Neurol Neurosci Rep 2017; 17(4): 32, https://doi.org/10.1007/s11910-017-0746-x.

24. Trimmel K., Sachsenweger J., Lindinger G., Auff E., Zimprich F., Pataraia E. Lateralization of language function in epilepsy patients: a high-density scalp-derived event-related potentials (ERP) study. Clin Neurophysiol 2017; 128(3): 472479, https://doi.org/10.1016/j.clinph.2016.12.025.

25. Tailby C., Abbott D.F., Jackson G.D. The diminishing dominance of the dominant hemisphere: language $\mathrm{FMRI}$ in focal epilepsy. Neuroimage Clin 2017; 14: 141-150, https://doi. org/10.1016/j.nicl.2017.01.011.

26. Kalamangalam G.P., Tandon N., Saria H.Y., Slater J.D. Asymmetric scalp electromyogram: a common and accurate lateralizing sign in motor seizures. J Clin Neurophysiol 2011; 28(5): 512-519, https://doi.org/10.1097/ wnp.0b013e318231c01f.

27. Mirzadjanova Z., Peters A.S., Rémi J., Bilgin C., Silva Cunha J.P., Noachtar S. Significance of lateralization of upper limb automatisms in temporal lobe epilepsy: a quantitative movement analysis. Epilepsia 2010; 51(10): 21402146, https://doi.org/10.1111/j.1528-1167.2010.02599.x.

28. Rémi J., Cunha J.P., Vollmar C., Topçuoğlu Ö.B.,
Meier A., Ulowetz S., Beleza P., Noachtar S. Quantitative movement analysis differentiates focal seizures characterized by automatisms. Epilepsy Behav 2011; 20(4): 642-647, https:// doi.org/10.1016/j.yebeh.2011.01.020.

29. Foldvary-Schaefer N., Unnwongse K. Localizing and lateralizing features of auras and seizures. Epilepsy Behav 2011; 20(2): 160-166, https://doi.org/10.1016/j.yebeh.2010.08.034.

30. Peters A.S., Rémi J., Vollmar C., GonzalezVictores J.A., Cunha J.P., Noachtar S. Dysprosody during epileptic seizures lateralizes to the nondominant hemisphere. Neurology 2011; 77(15): 1482-1486, https://doi.org/10.1212/ wnl.0b013e318232abae.

31. Bauer G., Broessner G., Unterberger I., Walser G., Pfausler B., Trinka E. Head turning as a prominent motor symptom in status epilepticus. Epileptic Disord 2008; 10(2): $119-129$.

32. Rémi J., Wagner P., O'Dwyer R., Silva Cunha J.P., Vollmar C., Krotofil I., Noachtar S. Ictal head turning in frontal and temporal lobe epilepsy. Epilepsia 2011; 52(8): 1447-1451, https://doi.org/10.1111/j.1528-1167.2011.03076.x.

33. Fernandes M.A., Smith M.L., Logan W., Crawley A., McAndrews M.P. Comparing language lateralization determined by dichotic listening and fMRI activation in frontal and temporal lobes in children with epilepsy. Brain Lang 2006; 96(1): 106-114, https://doi.org/10.1016/j.bandl.2005.06.006.

34. Bedoin N., Ferragne E., Lopez C., Herbillon V., De Bellescize J., des Portes V. Atypical hemispheric asymmetries for the processing of phonological features in children with rolandic epilepsy. Epilepsy Behav 2011; 21(1): 42-51, https://doi.org/10.1016/j.yebeh.2011.02.026.

35. Carlsson G., Wiegand G., Stephani U. Interictal and postictal performances on dichotic listening test in children with focal epilepsy. Brain Cogn 2011; 76(2): 310-315, https://doi. org/10.1016/j.bandc.2011.03.014.

36. Zaidi Z.F. Body asymmetries: incidence, etiology and clinical implications. Australian Journal of Basic and Applied Sciences 2011; 5(9): 2157-2191.

37. Chuprikov A.P. Mir levorukikh [The world of lefthanders]. Kiev: Institut neyropsikhiatrii A. Chuprikova, 2008.

38. Slezicki K.I., Cho Y.W., Yi S.D., Brock M.S., Pfeiffer M.H., McVearry K.M., Tractenberg R.E., Motamedi G.K. Incidence of atypical handedness in epilepsy and its association with clinical factors. Epilepsy Behav 2009; 16(2): 330-334, https://doi.org/10.1016/j.yebeh.2009.08.006.

39. Stewart C.C., Swanson S.J., Sabsevitz D.S., Rozman M.E., Janecek J.K., Binder J.R. Predictors of language lateralization in temporal lobe epilepsy Neuropsychologia 2014; 60: 93-102, https://doi.org/10.1016/j. neuropsychologia.2014.05.021.

40. Doležalová I., Schachter S., Chrastina J., Hemza J., Hermanová M., Rektor I., Pažourková M., Brázdil M. Atypical handedness in mesial temporal lobe epilepsy. Epilepsy Behav 2017; 72: 78-81, https://doi.org/10.1016/j.yebeh.2017.01.034.

41. Kalinin V.V., Zemlyanaya A.A., Krylov O.E., Zheleznova E.V. Handedness, alexithymia, and focus laterality as risk factors for psychiatric comorbidity in patients with epilepsy. Epilepsy Behav 2010; 17(3): 389-394, https://doi. org/10.1016/j.yebeh.2009.12.028.

42. Lin J.J., Riley J.D., Juranek J., Cramer S.C. Vulnerability of the frontal-temporal connections in temporal lobe epilepsy. Epilepsy Res 2008; 82(2-3): 162-170, https:// doi.org/10.1016/j.eplepsyres.2008.07.020.

43. Riley J.D., Franklin D.L., Choi V., Kim R.C., Binder D.K., 
Cramer S.C., Lin J.J. Altered white matter integrity in temporal lobe epilepsy: association with cognitive and clinical profiles. Epilepsia 2010; 51(4): 536-545, https://doi.org/10.1111/j.15281167.2009.02508.x.

44. Ung H., Cazares C., Nanivadekar A., Kini L., Wagenaar J., Becker D., Krieger A., Lucas T., Litt B., Davis K.A. Interictal epileptiform activity outside the seizure onset zone impacts cognition. Brain 2017; 140(8): 2157-2168, https://doi. org/10.1093/brain/awx143.

45. Caplan R., Siddarth P., Stahl L., Lanphier E., Vona P., Gurbani S., Koh S., Sankar R., Shields W.D. Childhood absence epilepsy: behavioral, cognitive, and linguistic comorbidities. Epilepsia 2008; 49(11): 1838-1846, https://doi. org/10.1111/j.1528-1167.2008.01680.x.

46. Rzezak P., Valente K.D., Duchowny M.S. Temporal lobe epilepsy in children: executive and mnestic impairments. Epilepsy Behav 2014; 31: 117-122, https://doi.org/10.1016/j. yebeh.2013.12.005.

47. Kanner A.M. Psychiatric comorbidities in new onset epilepsy: should they be always investigated? Seizure 2017; 49: 79-82, https://doi.org/10.1016/j.seizure.2017.04.007.

48. Helmstaedter C., Witt J.A. Epilepsy and cognition - a bidirectional relationship? Seizure 2017; 49: 83-89, https://doi. org/10.1016/j.seizure.2017.02.017.

49. Melikyan E.G., Guekht A.B. Effect of comorbidity on quality of life of patients with epilepsy. Zhurnal nevrologii $i$ psikhiatrii im. S.S. Korsakova 2011; 111(1): 91-97.

50. Kerr M.P., Mensah S., Besag F., de Toffol B., Ettinger A., Kanemoto K., Kanner A., Kemp S., Krishnamoorthy E., LaFrance W.C. Jr., Mula M., Schmitz B., van Elst L.T., Trollor J., Wilson S.J. International consensus clinical practice statements for the treatment of neuropsychiatric conditions associated with epilepsy. Epilepsia 2011; 52(11): 2133-2138, https://doi.org/10.1111/j.1528-1167.2011.03276.x.

51. Mula M. Depression in epilepsy. Curr Opin Neurol 2017; 30(2): 180-186, https://doi.org/10.1097/ wco.0000000000000431.

52. Elger C.E., Johnston S.A., Hoppe C. Diagnosing and treating depression in epilepsy. Seizure 2017; 44: 184-193, https://doi.org/10.1016/j.seizure.2016.10.018.

53. Bruder G.E., Tenke C.E., Warner V., Weissman M.M. Grandchildren at high and low risk for depression differ in EEG measures of regional brain asymmetry. Biol Psychiatry 2007; 62(11): 1317-1323, https://doi.org/10.1016/j.biopsych. Э2006.12.006.

54. Nusslock R., Shackman A.J., Harmon-Jones E., Alloy L.B., Coan J.A., Abramson L.Y. Cognitive vulnerability and frontal brain asymmetry: common predictors of first prospective depressive episode. J Abnorm Psychol 2011: 120(2): 497-503, https://doi.org/10.1037/a0022940.

55. Gandy M., Sharpe L., Perry K.N., Miller L., Thayer Z., Boserio J., Mohamed A. Anxiety in epilepsy: a neglected disorder. J Psychosom Res 2015; 78(2): 149-155, https://doi. org/10.1016/j.jpsychores.2014.12.002.

56. Loney J.C., Wirrell E.C., Sherman E.M., Hamiwka L.D. Anxiety and depressive symptoms in children presenting with a first seizure. Pediatr Neurol 2008; 39(4): 236-240, https://doi. org/10.1016/j.pediatrneurol.2008.07.005.

57. Ekinci O., Titus J.B., Rodopman A.A., Berkem M., Trevathan E. Depression and anxiety in children and adolescents with epilepsy: prevalence, risk factors, and treatment. Epilepsy Behav 2009; 14(1): 8-18, https://doi. org/10.1016/j.yebeh.2008.08.015.
58. Kanner A.M., Trimble M., Schmitz B. Postictal affective episodes. Epilepsy Behav 2010; 19(2): 156-158, https://doi. org/10.1016/j.yebeh.2010.06.024.

59. Reilly C., Agnew R., Neville B.G. Depression and anxiety in childhood epilepsy: a review. Seizure 2011; 20(8): 589-597, https://doi.org/10.1016/j.seizure.2011.06.004.

60. Kotov A.S. Anxiety in epileptic patients. Zhurnal nevrologii i psikhiatrii im. S.S. Korsakova 2013; 112(4-2): 41-44.

61. Hecimovic H., Salpekar J., Kanner A.M., Barry J.J. Suicidality and epilepsy: a neuropsychobiological perspective. Epilepsy Behav 2011; 22(1): 77-84, https://doi.org/10.1016/j. yebeh.2011.04.059.

62. Caplan R., Siddarth P., Levitt J., Gurbani S., Shields W.D., Sankar R. Suicidality and brain volumes in pediatric epilepsy. Epilepsy Behav 2010; 18(3): 286-290, https://doi.org/10.1016/j.yebeh.2010.04.018.

63. Dinkelacker V., Xin X., Baulac M., Samson S., Dupont S. Interictal epileptic discharge correlates with global and frontal cognitive dysfunction in temporal lobe epilepsy. Epilepsy Behav 2016; 62: 197-203, https://doi.org/10.1016/j. yebeh.2016.07.009.

64. Holmes G.L. Cognitive impairment in epilepsy: the role of network abnormalities. Epileptic Disord 2015; 17(2): 101-116.

65. Turovskaya N.G. Epilepsy and psychic developmental disorders: a literature review. Teoreticheskaya i eksperimentalnaya psikhologiya 2016; 9(3): 40-53.

66. Bell B., Lin J.J., Seidenberg M., Hermann B. The neurobiology of cognitive disorders in temporal lobe epilepsy. Nat Rev Neurol 2011; 7(3): 154-164, https://doi.org/10.1038/ nrneurol.2011.3.

67. Gauffin H., Flensner G., Landtblom A.M. Living with epilepsy accompanied by cognitive difficulties: young adults experiences. Epilepsy Behav 2011; 22(4): 750-758, https://doi. org/10.1016/j.yebeh.2011.09.007.

68. Alfstad K.A., Torgersen H., Van Roy B., Hessen E., Hansen B.H., Henning O., Clench-Aas J., Mowinckel P., Gjerstad L., Lossius M.I. Psychiatric comorbidity in children and youth with epilepsy: an association with executive dysfunction? Epilepsy Behav 2016; 56: 88-94, https://doi.org/10.1016/j. yebeh.2016.01.007.

69. Sepeta L.N., Casaletto K.B., Terwilliger V., FacellaErvolini J., Sady M., Mayo J., Gaillard W.D., Berl M.M. The role of executive functioning in memory performance in pediatric focal epilepsy. Epilepsia 2017; 58(2): 300-310, https://doi. org/10.1111/epi.13637.

70. Guzeva V.I., Belash V.O., Guzeva V.V., Guzeva O.V., Okembra Ibarra E.A. Peculiarities of cognitive functions in children with epilepsy. Zhurnal nevrologii $i$ psikhiatrii im. S.S. Korsakova 2008; 108(9): 24-28.

71. Nickels K.C., Zaccariello M.J., Hamiwka L.D., Wirrell E.C. Cognitive and neurodevelopmental comorbidities in paediatric epilepsy. Nat Rev Neurol 2016; 12(8): 465-476, https://doi.org/10.1038/nrneurol.2016.98.

72. Tolstova N.V., Kotov S.V., Kotov A.S. Cognitive functions in patients with idiopathic generalized and cryptogenic focal epilepsy. Zhurnal nevrologii i psikhiatrii im. S.S. Korsakova 2010; 110(10): 8-13.

73. Miller L.A., Galioto R., Tremont G., Davis J., Bryant K., Roth J., LaFrance W.C. Jr., Blum A.S. Cognitive impairment in older adults with epilepsy: characterization and risk factor analysis. Epilepsy Behav 2016; 56: 113-117, https://doi. org/10.1016/j.yebeh.2016.01.011. 
74. Brooks-Kayal A. Molecular mechanisms of cognitive and behavioral comorbidities of epilepsy in children. Epilepsia 2011; 52(Suppl 1): 13-20, https://doi.org/10.1111/j.15281167.2010.02906.x.

75. Shomakhova M.M., Lebedeva A.V., Ershov A.V., Khomutov V.E., Gudkova A.A. Predictors of cognitive disturbances in epilepsy. Zhurnal nevrologii i psikhiatrii im. S.S. Korsakova 2011; 111(5-2): 65-71.

76. Baca C.B., Vickrey B.G., Caplan R., Vassar S.D., Berg A.T. Psychiatric and medical comorbidity and quality of life outcomes in childhood-onset epilepsy. Pediatrics 2011; 128(6): e1532-e1543, https://doi.org/10.1542/peds.20110245.

77. Karouni M., Arulthas S., Larsson P.G., Rytter E., Johannessen S.I., Landmark C.J. Psychiatric comorbidity in patients with epilepsy: a population-based study. Eur J Clin Pharmacol 2010; 66(11): 1151-1160, https://doi.org/10.1007/ s00228-010-0861-y.

78. Voronkova K.V., Pylaeva O.A., Kholin A.A., Kosyakova E.S., Mazalskaya O.V., Koroleva N.Yu., Akhmedov T.M., Buchneva I.A., Petrukhin A.S. Side effects of antiepileptic therapy - modern state of the problem. Zhurnal nevrologii $i$ psikhiatrii im. S.S. Korsakova 2011; 111(10-2): 44-51.

79. Kovaleva I.J. Adverse effects of antiepileptic drugs. Epilepsiya i paroksizmalnye sostoyaniya 2017; 9(1): 51-61.

80. Irwin L.G., Fortune D.G. Risk factors for psychosis secondary to temporal lobe epilepsy: a systematic review. J Neuropsychiatry Clin Neurosci 2014; 26(1): 5-23, https://doi. org/10.1176/appi.neuropsych.12120403.

81. Karlov V.A. Pharmacoresistance and tolerability in epilepsy. Zhurnal nevrologii i psikhiatrii im. S.S. Korsakova 2008; 108(10): 75-81.

82. Hitiris N., Mohanraj R., Norrie J., Sills G.J., Brodie M.J. Predictors of pharmacoresistant epilepsy. Epilepsy Res 2007; 75(2-3): 192-196, https://doi.org/10.1016/j.eplepsyres. 2007.06.003.

83. Kanner A.M. Is depression a risk factor of worse response to therapy in epilepsy? Epilepsy Curr 2011; 11(2): 50-51, https://doi.org/10.5698/1535-7511-11.2.50.

84. Elger C.E., Hoppe C. What is depression in epilepsy? Front Neurol 2011; 2: 79, https://doi.org/10.3389/ fneur.2011.00079.

85. Wirrell E.C. Predicting pharmacoresistance in pediatric epilepsy. Epilepsia 2013; 54(Suppl 2): 19-22, https://doi. org/10.1111/epi.12179.

86. Russo A., Posar A., Conti S., Parmeggiani A. Prognostic factors of drug-resistant epilepsy in childhood: an Italian study. Pediatr Int 2015; 57(6): 1143-1148, https://doi.org/10.1111/ ped.12705.

87. Kotov A.S. Predictors of pharmacoresistance in adults with epilepsy. Annaly klinicheskoy i eksperimentalnoy nevrologii 2012; 6(1): 25-30.

88. Karlov V.A., Guekht A.B., Guzeva V.I., Lipatova L.V., Bazilevich S.N., Mkrtchyan V.R., Vlasov P.N., Zhidkova I.A., Mukhin K.Y., Petrukhin A.S., Lebedeva A.V. Algorithms of mono- and polytherapy in clinical epileptology. Part 1. General principles of drug choice. Zhurnal nevrologii $i$ psikhiatrii im. S.S. Korsakova 2016; 116(6): 109-114, https://doi. org/10.17116/jnevro201611661109-114.

89. Mula M. Epilepsy and psychiatric comorbidities: drug selection. Curr Treat Options Neurol 2017; 19(12): 44, https:// doi.org/10.1007/s11940-017-0483-0.
90. Zemlyanaya A.A., Kalinin V.V., Zheleznova E.V., Sokolova L.V. The changes in cognitive impairment in patients with epilepsy during the disease course (on example of executive functions). Zhurnal nevrologii $i$ psikhiatri im. S.S. Korsakova 2016; 116(9-2): 25-31, https://doi. org/10.17116/jnevro20161169225-31.

91. Kalinin V.V., Zemlyanaya A.A., Krylov O.E. Clinical characteristics and therapeutic dynamics in epilepsy with regard for functional brain organization. Sotsialnaya klinicheskaya psikhiatriya 2010; 20(3): 26-33.

92. Zemlianaia A.A., Kalinin V.V., Zheleznova E.V., Sokolova L.V. Personality and neurobiological factors as predictors of treatment efficacy in patients with partial epilepsy. Zhurnal nevrologii i psikhiatrii im. S.S. Korsakova 2012; 112(62): $72-77$.

93. Zemlianaia A.A., Kalinin V.V. Epilepsiya $i$ mezhpolusharnaya asimmetriya mozga. neyropsikhiatricheskie aspekty [Epilepsy and hemispheric asymmetry of the brain. Neuropsykhiatric aspects]. Saarbrucken: LAP Lambert Academic Publishing; 2012.

94. Zemlianaia A.A., Kalinin V.V. Influence of hemispheric asymmetry of the brain on the prognosis of the efficacy of antiseizure therapy in patients with pharmacoresistive epilepsy. Eksperimentalnaya i klinicheskaya farmakologiya 2015; 78(3, Suppl): 25-29.

95. Mohd-Tahir N.A., Li S.C. Meta-analyses of newer antiepileptic drugs as adjunct for treatment of focal epilepsy in children. Epilepsy Res 2017; 139: 113-122, https://doi org/10.1016/j.eplepsyres.2017.11.007.

96. Shih J.J., Whitlock J.B., Chimato N., Vargas E., Karceski S.C., Frank R.D. Epilepsy treatment in adults and adolescents: expert opinion, 2016. Epilepsy Behav 2017; 69: 186-222, https://doi.org/10.1016/j.yebeh.2016.11.018.

97. Kopylov F.U., Sokolova A.A., Lebedev G.S., Suchkov S.V., Chomakhidze P.S. Future development institute of precision medicine: new horizons of education and clinical activity. Meditsinskoe obrazovanie i vuzovskaya nauka 2017; 2(10): 12-17.

98. Rosenow F., van Alphen N., Becker A., Chiocchetti A., Deichmann R., Deller T., Freiman T., Freitag C.M., Gehrig J., Hermsen A.M., Jedlicka P., Kell C., Klein K.M., Knake S., Kullmann D.M., Liebner S., Norwood B.A., Omigie D., Plate K., Reif A., Reif P.S., Reiss Y., Roeper J., Ronellenfitsch M.W., Schorge S., Schratt G., Schwarzacher S.W., Steinbach J.P., Strzelczyk A., Triesch J., Wagner M., Walker M.C., von Wegner F., Bauer S. Personalized translational epilepsy research - novel approaches and future perspectives: Part I: clinical and network analysis approaches. Epilepsy Behav 2017; 76: 13-18, https://doi.org/10.1016/j.yebeh.2017. 06.041.

99. Bauer S., van Alphen N., Becker A., Chiocchetti A., Deichmann R., Deller T., Freiman T., Freitag C.M., Gehrig J., Hermsen A.M., Jedlicka P., Kell C., Klein K.M., Knake S., Kullmann D.M., Liebner S., Norwood B.A., Omigie D., Plate K., Reif A., Reif P.S., Reiss Y., Roeper J., Ronellenfitsch M.W., Schorge S., Schratt G., Schwarzacher S.W., Steinbach J.P., Strzelczyk A., Triesch J., Wagner M., Walker M.C., von Wegner F., Rosenow F. Personalized translational epilepsy research - novel approaches and future perspectives: Part II: experimental and translational approaches. Epilepsy Behav 2017; 76: 7-12, https://doi.org/10.1016/j.yebeh.2017.06.040.

100. Fedotchev A.I., Parin S.B., Polevaya S.A., Velikova S.D. Brain-computer interface and neurofeedback 
technologies: current state, problems and clinical prospects (review). Sovremennye tehnologii v medicine 2017; 9(1): 175184, https://doi.org/10.17691/stm2017.9.1.22.

101. Zemlyanaya A.A., Fedotcheva T.A., Fedotchev A.I. Modern approaches to human cognitive activity enhancement. Uspekhi fiziologicheskikh nauk 2010; 41(4): 45-62.

102. Fedotchev A.I., Zemlyanaya A.A., Polevaya S.A., Savchuk L.V. Attention deficit hyperactivity disorder and current possibilities of its treatment by the method of neurofeedback training. Zhurnal nevrologii $i$ psikhiatrii im. S.S. Korsakova 2016; 116(5): 98-101, https://doi.org/10.17116/ jnevro20161165198-101.

103. Fedotchev A., Radchenko G., Zemlianaia A. On one approach to health protection: music of the brain. $J$ Integr Neurosci 2017, https://doi.org/10.3233/jin-170053. [Epub ahead of print] 